\title{
Destruction of atherosclerotic plaque using pulse ultrasound with a planar rectangular transducer
}

\author{
Christakis Damianou ${ }^{1 *}$, Christos Christofi ${ }^{2}$, Nicos Mylonas ${ }^{3}$, Margarita Theodoulou ${ }^{4}$, Christos Makarounas ${ }^{4}$ \\ From Current and Future Applications of Focused Ultrasound 2014. 4th International Symposium \\ Washington, D.C, USA. 12-16 October 2014
}

\section{Background/introduction}

The aim of this paper is to present a feasibility study for using mechanical mode ultrasound for destroying atherosclerotic plaque with MRI monitoring.

\section{Methods}

An MRI safe flat rectangular $(3 \times 10 \mathrm{~mm} 2)$ transducer operating at $5 \mathrm{MHz}$ was used. A spatial average temporal average intensity of $10 \mathrm{~W} / \mathrm{cm} 2$ for $120 \mathrm{~s}$ was used, with DF of $10 \%$ and $1 \mathrm{~ms}$ pulse repetition period. This optimized protocol was applied in a rabbit model. The plaque in the rabbit was created using a $2 \%$ cholesterol diet.

\section{Results and conclusions}

During the course of the diet, the aorta of the rabbit was imaged using high resolution T2 W FSE every one month in order to assess the progress of the growth of the plaque. Selected rabbits were sacrificed in one, two, and three months since the initiation of the diet in order to assess the growth of the plaque histologically. Approximately $50 \%$ of the artery was covered by plaque in 3 months since the initiation of the diet. This was confirmed using MRI and histology. The proposed mechanical protocol has successfully destroyed plaque in the aorta of the rabbit. The size of the rabbit aorta has similar size with the coronary or carotid arteries in humans. The rabbit is a good model for creating atherosclerotic plaque.

\section{Acknowledgements (Funding)}

This work was supported by the Research Promotion Foundation (RPF) of

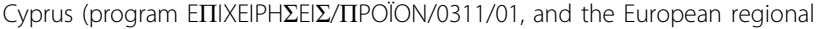
development structural funds).
Authors' details

'MEDSONIC, LTD, Limassol, Cyprus. ${ }^{2}$ The Cyprus Institute, Limassol, Cyprus.

${ }^{3}$ Frederick Research Center, Limassol, Cyprus. ${ }^{4}$ Cyprus University of

Technology, Limassol, Cyprus.

Published: 30 June 2015

doi:10.1186/2050-5736-3-S1-072

Cite this article as: Damianou et al: Destruction of atherosclerotic plaque using pulse ultrasound with a planar rectangular transducer. Journal of Therapeutic Ultrasound 2015 3(Suppl 1):072.
Submit your next manuscript to BioMed Central and take full advantage of:

- Convenient online submission

- Thorough peer review

- No space constraints or color figure charges

- Immediate publication on acceptance

- Inclusion in PubMed, CAS, Scopus and Google Scholar

- Research which is freely available for redistribution
() Biomed Central
C Biomed Central

(C) 2015 Damianou et al; licensee BioMed Central Ltd. This is an Open Access article distributed under the terms of the Creative Commons Attribution License (http://creativecommons.org/licenses/by/4.0), which permits unrestricted use, distribution, and reproduction in any medium, provided the original work is properly cited. The Creative Commons Public Domain Dedication waiver (http://creativecommons.org/publicdomain/zero/1.0/) applies to the data made available in this article, unless otherwise stated. 